\title{
Syntheses and Characterization of Benzotriazole, Thienopyrroledione, and Benzodithiophene Containing Conjugated Random Terpolymers for Organic Solar Cells
}

\author{
Kardelen Goksu, ${ }^{1}$ Gonul Hizalan, ${ }^{2}$ Yasemin Arslan Udum, ${ }^{3}$ Serife Ozdemir Hacioglu, ${ }^{4}$ \\ Sevki Can Cevher, ${ }^{1}$ Akrema, ${ }^{1}$ Levent Toppare,,${ }^{1,2,5,6}$ and Ali Cirpan ${ }^{1,2,5,7, z}$ \\ ${ }^{1}$ Department of Chemistry, Middle East Technical University, 06800 Ankara, Turkey \\ ${ }^{2}$ The Center for Solar Energy Research and Application (GUNAM), Middle East Technical University, 06800 Ankara, \\ Turkey \\ ${ }^{3}$ Technical Sciences, Vocational High School, Gazi University, 06374, Turkey \\ ${ }^{4}$ Department of Basic Sciences of Engineering, Iskenderun Technical University, 31200, Hatay, Turkey \\ ${ }^{5}$ Department of Polymer Science and Technology, Middle East Technical University, 06800 Ankara, Turkey \\ ${ }^{6}$ Department of Biotechnology, Middle East Technical University, 06800 Ankara, Turkey \\ ${ }^{7}$ Department of Micro and Nanotechnology, Middle East Technical University, 06800 Ankara, Turkey
}

\begin{abstract}
Two random terpolymers bearing alkoxy-benzodithiophene as an electron-rich unit and N-octylthieno[3,4,c]pyrrole-4,6-dione (TPD) as an electron deficient group with thiophene and selenophene $\pi$ bridges, were synthesized and characterized. Electrochemical, optical properties of the polymers were analyzed to get an insight on the effect of different $\pi$ bridges. Photovoltaic performances of the polymers were investigated with a conventional device architecture. PBTS, PBTSe based polymer solar cells (PSCs) exhibited power conversion efficiency of $3.32 \%$ and $3.19 \%$. PCE of PBTS:PC ${ }_{71} \mathrm{BM}$ based PSCs were improved to $4.30 \%$ with the addition of $1 \%$ (vol/vol) 1,8-diiodooctane (DIO) as a solution processing additive. With the introduction of diphenyl ether (DPE) as the solvent additive, PBTSe based polymer solar cells attained 5.15\% PCE value due to the formation of the interpenetrated network structure of domains.

(C) 2019 The Electrochemical Society. [DOI: 10.1149/2.1161915jes]
\end{abstract}

Manuscript submitted September 18, 2019; revised manuscript received November 4, 2019. Published November 20, 2019.

In today's world, there exists enormous energy consumption and this consumption is increasing day by day reaching terawatt magnitude as the human population increase. ${ }^{1-5}$ The requirement of supplies are commonly fulfilled from energy sources like oil, natural gas, coal and other fuels. ${ }^{6-8}$ The primary concern of using non-renewable energy sources is the emission of greenhouse gases. ${ }^{9}$ The environmental concern attracted researchers toward green sources like solar energy which has limitless energy capacity, cleanness, and renewability. ${ }^{1}$

Organic materials have the potential to foster a lasting technology that is economically feasible for power generation based on eco-friendly materials with unrestricted accessibility. Organic semiconductors can be an alternative to inorganic semiconductors as these are cost-effective and have extremely high optical absorption coefficients which extend the possibility for the construction of ultra thin solar cells. Additionally, organic solar cells have shown the possibilities for flexible devices using high throughput, low-temperature approaches that employ well established roll-to-roll process. ${ }^{10,11}$

Polymer organic solar cells have remarkable advantages such as low cost, light weight, ease of processability and flexibility; Therefore, these are more applicable for the last two decades over their counterparts. ${ }^{12-14}$ Recent studies show that device performances have surpassed $10 \%$ with the maximum $17 \%$ PCE by varying donoracceptor moieties and device engineering. ${ }^{15-19}$ The photoactive layer consists of p-type donor and n-type acceptor materials sandwiched between two electrodes. ${ }^{20,21}$ Various non-fullerene ${ }^{22-25}$ and fullerene ${ }^{26-28}$ based acceptor units have been used in the active layer with polymerbased donors and solar efficiencies reported as $16.4 \%{ }^{29}$ and $17.3 \%{ }^{26}$ respectively. Fullerene-based structures such as $\mathrm{PC}_{61} \mathrm{BM}$ and $\mathrm{PC}_{71} \mathrm{BM}$ are used as acceptors in the active layer since they possess high electron mobility, high electron affinity, good interpenetrating network system with electron donor polymers and large absorption coefficient in the visible region in addition to their good solubility in common organic solvents such as chlorobenzene, chloroform and $o$-dichlorobenzene. ${ }^{27,30-36}$ The efficiency of solar cells can be improved by identifying the arising problems such as short-circuit current density $\left(\mathrm{J}_{\mathrm{SC}}\right)$, poor fill factor, open-circuit voltage $\left(\mathrm{V}_{\mathrm{OC}}\right)$, charge mobility and poor surface morphology of active layer. ${ }^{5}$ Up to now, many modifications have been applied to obtain narrow bandgap donor- acceptor type polymers, for broad light harvesting from solar spectra, with low-lying HOMO energy level that help to enhance open circuit voltage. ${ }^{37-43} \mathrm{~A}$ high $\mathrm{V}_{\mathrm{OC}}$ value is achieved by adjusting the HOMO energy level of polymer which has a direct relationship with the HOMO level of donor and LUMO energy level of acceptor moieties i.e. $\mathrm{PC}_{71} \mathrm{BM}^{44,45}$

One of the popular structural designs of conjugated polymer is introducing a third component into the carbon backbone chain of the D-A copolymer. Terpolymers contain three different building blocks which means different properties can be achieved via their combination. Hence three units in the terpolymer cause synergistic effects such as improved molecular energy levels, broad light absorption by the appearance of a new $\pi-\pi^{*}$ or interchain charge transfer (ICT) peaks, improved solubility, miscibility with fullerene leading to better domain morphology and charge carrier mobility. Lately, terpolymer incorporated solar cell efficiencies ${ }^{46-49}$ have been reported with maximum PCE of $16.4 \% .{ }^{29}$ There are several donor and acceptor segments suitable for the design of copolymers. Among them, benzodithiophene (BDT) shows great electron donor properties due to its electron-rich $\pi$-conjugation system and benzene with coherent thiophene ring increases the planarity. Moreover, high open circuit voltage was achieved by BDT containing polymers with a low lying HOMO energy levels. By introducing alkoxy groups to BDT, solubility of the resulting polymer is enhanced. As an electron deficient unit, thienopyrrolodione (TPD) is widely used due to its diimide groups. This leads to have a lower bandgap via stabilizing LUMO of the polymer..$^{50}$ Another known electron-withdrawing group is benzotriazole which is a heterocyclic benzazole derivative with electron deficient imine bonds promising improved photovoltaic performances. ${ }^{51}$ Cabanetos and coauthors have designed a copolymer based on alkoxy substituted BDT and alkylated-TPD which attained a PCE of 7\%. ${ }^{52}$ In 2017, Lee et al. reported alkoxy-BDT and $N$-alkyl TPD containing polymers with PCEs ranging between $2.8 \%$ to $6.6 \%$ via different modifications. ${ }^{53}$ In our previous report, Azeri et al. synthesized a terpolymer based on benzotriazole (BTz), thienopyrrolodione (TPD) and benzodithiophene (BDT) and the $2.55 \%$ PCE value was achieved. ${ }^{54}$

Recent years have witnessed the evolution of polyselenophenes, both theoretically and experimentally. Some promising properties like lower band gaps, red-shifted absorption, and better polarizability compared to polythiophenes make them feasible for application in organic solar cells as confirmed by experiments. ${ }^{55-57}$ The favorable properties 
of polyselenophenes and selenophene attracted the researchers. Selenophene containing polymers have been employed in organic solar cells in the last years. ${ }^{58-61}$ A series of selenophene- and biselenophenesubstituted diketopyrrolopyrroles were used in solution-processed bulk-heterojunction (BHJ) solar cells, whereby PCEs of $1.5 \%$ were achieved. ${ }^{62}$

By taking into consideration of literature knowledge, we modified two random terpolymers namely PBTS and PBTSe, involving alkoxysubstituted benzodithiophene as the donor, thienopyrrolodione and benzotriazole as the acceptors. Thiophene and selenophene were introduced as a spacer to BTz unit into the terpolymer structure in order to investigate $\pi$-bridge alteration effect on device performances.

\section{Experimental}

Measurement and characterization.-Chemical reagents were commercially available and were used as received. Tetrahydrofuran (THF) was freshly distilled from benzophenone ketyl and sodium metal under inert atmosphere. Other solvents were of analytical grade and used without further purification. For characterization of synthesized compounds, NMR spectra were taken on Bruker Spectrospin Avance DPX-400 Spectrometer and chemical shifts were determined relative to the internal standard tetramethylsilane (TMS) in deuterochloroform solvent. Gel permeation chromatography (GPC) was performed using Shimadzu RID-20 A with chloroform as the eluent and polystyrene as the universal calibration standart to investigate average molecular weights of synthesized polymers. For detection of thermal behaviors of PBTS and PBTSe, thermal gravimetry analysis and differential scanning calorimetry were studied with Perkin Elmer Pyris 1 TGA and Perkin Elmer Diamond DSC, respectively. UV-Vis absorption spectroscopy was performed using a JASCO V-770 spectrophotometer for both solution in chloroform and as a thin film of PBTS and PBTSe. Emission spectra were obtained with Perkin Elmer LS 55 Fluorescence spectrometer. Cyclic voltammetry was performed on Gamry 600 electrochemical workstation with a three-electrode system in a solution of $0.1 \mathrm{M} \mathrm{TBAPF}_{6}$ acetonitrile solution at a scan rate of $100 \mathrm{mV} / \mathrm{s}$.

Synthesis.-(1), (2) and (3) were synthesized according to the previously reported procedures. ${ }^{63}$

Tributyl(thiophen-2-yl)stannane (4).- Thiophene $(2.00 \mathrm{~g}$, $23.77 \mathrm{mmol}$ ) was dissolved in $30 \mathrm{~mL}$ of freshly distilled THF (dry) under argon atmosphere. The reaction was stirred for a while and the flask was placed in a cryostat at $-78{ }^{\circ} \mathrm{C}$. n-BuLi $(9.00 \mathrm{~mL}$, $22.5 \mathrm{mmol}, 2.5 \mathrm{M}$ in hexane) was added drop wise over $6 \mathrm{~h}$ and subsequently, the reaction was stirred for $1 \mathrm{~h}$. Further, tributyltin chloride (8.51 g, $26.15 \mathrm{mmol}, 97 \%)$ was added slowly over $4 \mathrm{~h}$ and the mixture was stirred for an additional hour. Finally, it was removed from cryostat and stirred overnight at room temperature. THF was evaporated under reduced pressure. $5 \mathrm{~mL}$ distilled water was added to flask and extraction was performed with dichloromethane and brine. The organic residue was dried over $\mathrm{MgSO}_{4}$ and the solvent was evaporated by rotary evaporator. A viscous pale yellow oil was obtained (8.5 g, yield 96\%); ${ }^{1} \mathrm{H}$ NMR $\left(400 \mathrm{MHz}, \mathrm{CDCl}_{3}\right), \delta(\mathrm{ppm})$ : $7.57(\mathrm{~d}, J=4.7 \mathrm{~Hz}, 1 \mathrm{H}), 7.19(\mathrm{dd}, J=4.6,3.2 \mathrm{~Hz}, 1 \mathrm{H}), 7.12(\mathrm{~d}, J=$ $3.2 \mathrm{~Hz}, 1 \mathrm{H}), 1.50(\mathrm{t}, J=7.3 \mathrm{~Hz}, 6 \mathrm{H}), 1.26(\mathrm{~m}, 6 \mathrm{H}), 1.06-1.01(\mathrm{~m}$, $6 \mathrm{H}), 0.81(\mathrm{t}, J=7.3 \mathrm{~Hz}, 9 \mathrm{H}) ;{ }^{13} \mathrm{C} \mathrm{NMR}\left(101 \mathrm{MHz}, \mathrm{CDCl}_{3}\right), \delta(\mathrm{ppm})$ $136.19,135.18,130.58,127.83,28.97,27.27,13.67,10.82$.

Tributyl(selenophen-2-yl)stannane (5).-Selenophene (2.56 g, $19.54 \mathrm{mmol}$ ) was dissolved in $35 \mathrm{~mL}$ of freshly distilled THF under inert atmosphere. The reaction was stirred for a while and the flask was placed in a cryostat at $-78^{\circ} \mathrm{C}$. $\mathrm{n}-\mathrm{BuLi}(7.42 \mathrm{~mL}, 18.56 \mathrm{mmol}$, $2.5 \mathrm{M}$ in hexane) was added drop wise over $6 \mathrm{~h}$ and stirred for an additional hour. Tributyltin chloride (7.00 g, $21.49 \mathrm{mmol}, 97 \%)$ was added slowly over $4 \mathrm{~h}$ and stirred further for $1 \mathrm{~h}$. The reaction was stirred overnight at room temperature. THF was removed under reduced pressure and $10 \mathrm{~mL}$ distilled water were added to the flask and extraction was performed with dichloromethane, sodium bicarbonate $\left(\mathrm{NaHCO}_{3}\right)$ and brine. The organic residue was dried over $\mathrm{MgSO}_{4}$ and the solvent was evaporated by rotary evaporator. The viscous pale yellow oil was obtained. $(7.7 \mathrm{~g}$, yield $94 \%) ;{ }^{1} \mathrm{H} \mathrm{NMR}\left(400 \mathrm{MHz}, \mathrm{CDCl}_{3}\right)$, $\delta(\mathrm{ppm}): 8.54(\mathrm{~d}, J=4.9 \mathrm{~Hz}, 1 \mathrm{H}), 7.76(\mathrm{~d}, J=3.3 \mathrm{~Hz}, 1 \mathrm{H}), 7.71(\mathrm{dd}$, $J=5.1,3.4 \mathrm{~Hz}, 1 \mathrm{H}), 1.85(\mathrm{~m}, 6 \mathrm{H}), 1.65-1.58(\mathrm{~m}, 6 \mathrm{H}), 1.42-1.33(\mathrm{~m}$, $6 \mathrm{H}), 1.17$ (t, $J=9.4 \mathrm{~Hz}, 9 \mathrm{H}) ;{ }^{13} \mathrm{C}$ NMR $\left(101 \mathrm{MHz}, \mathrm{CDCl}_{3}\right), \delta(\mathrm{ppm})$ $143.35,138.03,135.45,130.64,29.25,27.54,13.89,11.33$.

3-(Bromomethyl)heptane (6).-To a solution of 2-ethylhexan-1ol $(10.00 \mathrm{~g}, 76.79 \mathrm{mmol})$ in methylene chloride (DCM) $(120 \mathrm{~mL})$, triphenylphosphine $\left(\mathrm{PPh}_{3}\right)(20.48 \mathrm{~g}, 78.10 \mathrm{mmol})$ was added and the temperature was set to $0^{\circ} \mathrm{C}$ in an ice bath. Bromine $(11.36 \mathrm{~mL}$, $221.47 \mathrm{mmol}$ ) in $5 \mathrm{~mL}$ methylene chloride was added drop wise to the reaction mixture at $0^{\circ} \mathrm{C}$. The reaction was stirred overnight at room temperature. The reaction was poured into freshly prepared saturated sodium bisulfite $\left(\mathrm{NaHSO}_{3}\right)$ solution. Extraction was performed with DCM and distilled water several times. The combined organic phase was dried over $\mathrm{MgSO}_{4}$ and the solvent was evaporated under reduced pressure. The obtained product was purified by column chromatography on silica gel using hexane $(12.6 \mathrm{~g}, 85 \%)$ to obtain a colorless oil; ${ }^{1} \mathrm{H}$ NMR (400 MHz, CDCl3), $\delta$ (ppm): 3.67 - 3.19 (m, 2H), $1.68-$ $1.08(\mathrm{~m}, 9 \mathrm{H}), 1.08-0.67(\mathrm{~m}, 6 \mathrm{H}) ;{ }^{13} \mathrm{C} \mathrm{NMR}\left(101 \mathrm{MHz}, \mathrm{CDCl}_{3}\right), \delta$ (ppm): 41.1, 38.93, 31.89, 28.83, 25.17, 22.85, 14.02, 10.84.

4,7-Dibromo-2-(2- ethylhexyl)-2H-benzo[d][1,2,3]triazole (7).Nitrogen purged a two neck round bottom flask was filled with compound 3 (3.00 g, $10.83 \mathrm{mmol})$ and $20 \mathrm{~mL}$ anhydrous dimethylformamide (DMF) at $0^{\circ} \mathrm{C}$. Sodium hydride $(\mathrm{NaH})(317 \mathrm{mg}, 13.2 \mathrm{mmol}$, $60 \%$ in oil) was added and the reaction was stirred for $1 \mathrm{~h}$ and then the temperature was raised to $70^{\circ} \mathrm{C}$. Then, compound $6(2.5 \mathrm{~g}$, $12.97 \mathrm{mmol}$ ) was added to the reaction flask and the medium was stirred for overnight. The crude product was washed four times with chloroform and distilled water. The organic phase was dried with a drying agent $\left(\mathrm{MgSO}_{4}\right)$. For further purification, column chromatography on silica gel with hexane:ethyl acetate (1:1) was performed and desired compound was obtained as a viscous yellow oil $(2.0 \mathrm{~g}$, yield $59 \%) ;{ }^{1} \mathrm{H}$ NMR (400 MHz, $\left.\mathrm{CDCl}_{3}\right), \delta(\mathrm{ppm}): 7.41$ (s, 2H), 4.67 (d, $J=7.3 \mathrm{~Hz}, 2 \mathrm{H}), 2.34-2.28(\mathrm{~m}, 1 \mathrm{H}), 1.41-1.23(\mathrm{~m}, 8 \mathrm{H}), 0.94-0.85(\mathrm{~m}$, $6 \mathrm{H}) ;{ }^{13} \mathrm{C} \mathrm{NMR}\left(101 \mathrm{MHz}, \mathrm{CDCl}_{3}\right), \delta$ (ppm): 143.5, 129.18, 109.82, $61.02,40.23,30.29,28.11,23.74,22.91,13.79,10.33$.

2-(2-Ethylhexyl)-4,7-di(thiophen-2-yl)-2H-benzo[d][1,2,3]triazole (8). $-7(1.11 \mathrm{~g}, 2.84 \mathrm{mmol})$ and $4(3.18 \mathrm{~g}, 8.52 \mathrm{mmol})$ were put in a $250 \mathrm{~mL}$ two neck round bottom flask under a nitrogen atmosphere. Dry THF was added and bubbling was performed for 45 minutes. Bis(triphenylphosphine)palladium(II) dichloride $\left(\mathrm{Pd}\left(\mathrm{PPh}_{3}\right)_{2} \mathrm{Cl}_{2}\right)$ (99.5 mg, $5 \mathrm{~mol} \%$ ) was added to the reaction media immediately and temperature was raised to $80^{\circ} \mathrm{C}$. The reaction was stirred for $5 \mathrm{~h}$ and an additional $5 \mathrm{~mol} \%$ catalyst was added to the flask and stirred overnight. The reaction was monitored by thin layer chromatography and water was added to quench the reaction. Extraction was performed with chloroform and brine. The resulting residue was dried over $\mathrm{MgSO}_{4}$ and chloroform was removed under reduced pressure. Further purification was done with column chromatography (hexane:ethyl acetate) (2:1). The final product was a yellow solid. (870 $\mathrm{mg}$, yield $78 \%$ ); ${ }^{1} \mathrm{H}$ NMR (400 MHz, $\left.\mathrm{CDCl}_{3}\right) \delta(\mathrm{ppm}): 8.12$ (dd, $J=3.7$, $1.0 \mathrm{~Hz}, 2 \mathrm{H}), 7.63$ (s, 2H), $7.39(\mathrm{dd}, J=5.1,1.0 \mathrm{~Hz}, 2 \mathrm{H}), 7.20(\mathrm{dd}, J$ $=5.1,3.7 \mathrm{~Hz}, 2 \mathrm{H}), 4.76(\mathrm{~d}, J=6.7 \mathrm{~Hz}, 2 \mathrm{H}), 2.34-2.25(\mathrm{~m}, 1 \mathrm{H})$, $1.00(\mathrm{~m}, 8 \mathrm{H}), 0.91(\mathrm{t}, J=7.2 \mathrm{~Hz}, 6 \mathrm{H}) ;{ }^{13} \mathrm{C} \mathrm{NMR}\left(101 \mathrm{MHz}, \mathrm{CDCl}_{3}\right)$ $\delta(\mathrm{ppm}): 142.02,140.05,128.09,126.96,125.53,123.58,122.66$, $59.72,40.46,30.62,28.51,24.02,22.97,14.08,10.59$.

2-(2-Ethylhexyl)-4,7-di(selenophen-2-yl)-2H-benzo[d][1,2,3]triazole (9).-A $100 \mathrm{~mL}$ round bottom flask was filled with 7 (700 mg, $1.8 \mathrm{mmol})$ and $\mathbf{5}(3.02 \mathrm{~g}, 7.20 \mathrm{mmol})$ under nitrogen atmosphere in THF. The reaction was stirred for $30 \mathrm{~min}$. $\mathrm{Pd}\left(\mathrm{PPh}_{3}\right)_{2} \mathrm{Cl}_{2}(63 \mathrm{mg}$, $5 \mathrm{~mol} \%$ ) was added as the catalyst and the temperature was raised to $80^{\circ} \mathrm{C}$. The reaction was stirred for $4 \mathrm{~h}$ and an additional $5 \mathrm{~mol} \%$ 
catalyst were introduced into a flask and stirred overnight at reflux temperature. The reaction was monitored by thin layer chromatography and the reaction mixture was poured into water. Extraction was performed with chloroform and brine. The resulting residue was dried over $\mathrm{MgSO}_{4}$ and the solvent was removed under reduced pressure. Further purification was done with column chromatography (hexane:ethyl acetate) $(5: 1)$. The final product was a yellow solid. (650 mg, yield 74\%); ${ }^{1} \mathrm{H}$ NMR (400 MHz, $\mathrm{CDCl}_{3}$ ), $\delta$ (ppm): 8.20 $(\mathrm{dd}, J=3.8,0.8 \mathrm{~Hz}, 2 \mathrm{H}), 8.09(\mathrm{dd}, J=5.6,0.8 \mathrm{~Hz}, 2 \mathrm{H}), 7.61(\mathrm{~s}, 2 \mathrm{H})$, $7.43(\mathrm{dd}, J=5.6,3.9 \mathrm{~Hz}, 2 \mathrm{H}), 4.76(\mathrm{~d}, J=6.6 \mathrm{~Hz}, 2 \mathrm{H}), 2.34-2.19$ $(\mathrm{m}, 1 \mathrm{H}), 1.47-1.29(\mathrm{~m}, 8 \mathrm{H}), 1.02(\mathrm{t}, J=7.4 \mathrm{~Hz}, 3 \mathrm{H}), 0.92(\mathrm{t}, J=$ $7.2 \mathrm{~Hz}, 3 \mathrm{H}) ;{ }^{13} \mathrm{C} \mathrm{NMR}\left(101 \mathrm{MHz}, \mathrm{CDCl}_{3}\right) \delta 145.19,141.85,131.50$, $130.46,128.07,125.41,122.84,59.56,40.50,30.68,28.57,24.07$, $22.97,14.10,10.65$.

4,7-Bis(5-bromothiophen-2-yl)-2-(2-ethylhexyl)-2H-benzo[d][1,2,3] triazole $(10, M 1)$. $\mathbf{8}(500 \mathrm{mg}, 1.26 \mathrm{mmol})$ was dissolved in $50 \mathrm{~mL}$ chloroform and the reaction flask was covered with aluminum foil to protect the reactants from light. $N$-bromosuccinimide (NBS) (562.41 mg, $3.16 \mathrm{mmol}$ ) was added in several portions over $6 \mathrm{~h}$ and the reaction was stirred overnight at $30^{\circ} \mathrm{C}$. Extraction was done with chloroform-water for three times and then the combined organic phase was dried over $\mathrm{MgSO}_{4}$. The crude product was purified by recrystallization from ethanol three times and obtained crystals were loaded to silica gel column chromatography, using chloroform as eluent. The desired pure product was collected as a yellow solid. (590 mg, yield 84\%); ${ }^{1} \mathrm{H}$ NMR (400 MHz, $\mathrm{CDCl}_{3}$ ) $\delta(\mathrm{ppm}): 7.77$ (d, $J=3.9 \mathrm{~Hz}, 2 \mathrm{H}), 7.46(\mathrm{~s}, 2 \mathrm{H}), 7.11(\mathrm{~d}, J=3.9 \mathrm{~Hz}, 2 \mathrm{H}), 4.72(\mathrm{~d}, J=$ $6.7 \mathrm{~Hz}, 2 \mathrm{H}), 2.32-2.19(\mathrm{~m}, 1 \mathrm{H}), 1.47-1.26(\mathrm{~m}, 8 \mathrm{H}), 0.98(\mathrm{t}, J=$ $7.4 \mathrm{~Hz}, 3 \mathrm{H}), 0.91(\mathrm{t}, J=7.2 \mathrm{~Hz}, 3 \mathrm{H}) ;{ }^{13} \mathrm{C} \mathrm{NMR}\left(101 \mathrm{MHz}, \mathrm{CDCl}_{3}\right)$ $\delta 141.61,141.30,130.87,126.90,122.95,122.08,113.18,59.77$, $40.46,30.59,28.46,24.01,22.98,14.08,10.59$.

\section{4,7-Bis(5-bromoselenophen-2-yl)-2-(2-ethylhexyl)-2H-benzo[d]} [1,2,3]triazole $(11, M 2)$. $-9(500 \mathrm{mg}, 1.02 \mathrm{mmol})$ was dissolved in $50 \mathrm{~mL}$ chloroform and the reaction flask was protected from light with aluminum foil. $N$-bromosuccinimide (NBS) $(454 \mathrm{mg}, 2.55 \mathrm{mmol}$ ) was added in small portions over $5 \mathrm{~h}$. The reaction was stirred overnight. The crude product was extracted with chloroform-water and the combined organic phase was dried over $\mathrm{MgSO}_{4}$. The crude product was purified by recrystallization from ethanol two times and then obtained crystals were loaded to silica gel column chromatography, using 10:0.1 petroleum ether, dichloromethane as eluent couple. The pure product was collected as a yellow solid. (550 $\mathrm{mg}$, yield $83 \%$ ); ${ }^{1} \mathrm{H}$ NMR $\left(400 \mathrm{MHz}, \mathrm{CDCl}_{3}\right) \delta(\mathrm{ppm}): 7.76(\mathrm{~d}, J=4.2 \mathrm{~Hz}, 2 \mathrm{H}), 7.49$ $(\mathrm{s}, 2 \mathrm{H}), 7.32(\mathrm{~d}, J=4.2 \mathrm{~Hz}, 2 \mathrm{H}), 4.71(\mathrm{~d}, J=6.5 \mathrm{~Hz}, 2 \mathrm{H}), 2.16-$ $2.11(\mathrm{~m}, 1 \mathrm{H}), 1.50-1.38(\mathrm{~m}, 8 \mathrm{H}), 1.00(\mathrm{t}, J=7.4 \mathrm{~Hz}, 3 \mathrm{H}), 0.91(\mathrm{t}$, $J=7.2 \mathrm{~Hz}, 3 \mathrm{H}) ;{ }^{13} \mathrm{C} \mathrm{NMR}\left(101 \mathrm{MHz}, \mathrm{CDCl}_{3}\right) \delta 141.61,141.30$, $130.87,126.90,122.95,122.08,113.18,59.77,40.46,30.59,28.46$, $24.01,22.98,14.08,10.59$.

Synthesis of copolymers.-PBTS.-Nitrogen purged a $100 \mathrm{~mL}$ two-necked flask was filled with compound 10 (M1) $(167 \mathrm{mg}$, $0.29 \mathrm{mmol}), 1,3$-dibromo-5-octyl-4H-thieno[3,4-c]pyrrole-4,6(5H)dione (128 mg, $0.29 \mathrm{mmol}), 4,8$-bis((2-ethylhexyl)oxy)benzo[1,2$b: 4,5-b$ '] dithiophene-2,6diyl)bis(trimethyl stannane) (467 mg, $0.58 \mathrm{mmol}$ ), freshly distilled THF and was flushed with nitrogen for 45 minutes. Subsequently, $\mathrm{Pd}\left(\mathrm{PPh}_{3}\right)_{2} \mathrm{Cl}_{2}(21 \mathrm{mg}, 10 \mathrm{~mol} \%)$ was added and the temperature was increased to $85^{\circ} \mathrm{C}$. The reaction mixture was stirred for $40 \mathrm{~h}$. An additional amount of $\mathrm{Pd}\left(\mathrm{PPh}_{3}\right)_{2} \mathrm{Cl}_{2}$ $(6.4 \mathrm{mg}, 3 \mathrm{~mol} \%)$ was introduced into the reaction. The first end capper, 2-bromothiophene, (147 mg, $0.96 \mathrm{mmol})$ was added and after $4 \mathrm{~h}$ a second end capper, 2-tributylstanylthiophene, $(676 \mathrm{mg}$, $1.8 \mathrm{mmol}$ ) was introduced. The reaction mixture was stirred for an additional $6 \mathrm{~h}$. The solvent was evaporated under reduced pressure. The residue was dissolved in a minimum amount of chloroform and precipitated into cold methanol. Polymer purification was done using Soxhlet extraction with acetone $(4 \mathrm{~h})$ and hexane $(12 \mathrm{~h})$, respectively, to remove dimer, trimer and oligomers. The desired polymer was collected with chloroform. The solvent was removed and the remnant was precipitated in cold methanol as dark purple solid beans. The solution was filtered to obtain a purified polymer $(410 \mathrm{mg}$, yield $88 \%)$. GPC data were reported as: Number-average molecular weight $(\mathrm{Mn})=24 \mathrm{kDa}$, Weight-Average molecular weight $(\mathrm{Mw})=36 \mathrm{kDa}$. Polydispersity index $(\mathrm{PDI})=1.5$.

PTBSe.- 11 (M2) (150 mg, $0.23 \mathrm{mmol})$, 1,3-dibromo-5-octyl4H-thieno[3,4-c]pyrrole-4,6 $(5 \mathrm{H})$-dione $(98.08 \mathrm{mg}, 0.23 \mathrm{mmol})$ and 4,8-bis((2-ethylhexyl)oxy)benzo[1,2-b:4,5-b']dithiophene-2,6 diyl)bis(trimethylstannane) (358 $\mathrm{mg}, 0.46 \mathrm{mmol}$ ) and dry THF were charged into a $100 \mathrm{~mL}$ two neck flask under inert atmosphere. The reaction mixture was stirred for $45 \mathrm{~min}$ and then $\mathrm{Pd}\left(\mathrm{PPh}_{3}\right)_{2} \mathrm{Cl}_{2}$ (16 mg, $10 \mathrm{~mol} \%$ ) was added. The temperature was raised to $85^{\circ} \mathrm{C}$ and the reaction mixture was stirred for $40 \mathrm{~h}$. Excess amount of $\left(\mathrm{Pd}\left(\mathrm{PPh}_{3}\right)_{2} \mathrm{Cl}_{2}\right)(5.0 \mathrm{mg}, 3 \mathrm{~mol} \%)$ was introduced to the reaction. The first end capper, 2-bromothiophene, $(112 \mathrm{mg}, 0.69 \mathrm{mmol})$ was added and after $4 \mathrm{~h}$ second end capper, 2-tributylstanylthiophene, (515 mg, $1.38 \mathrm{mmol}$ ) was loaded. The reaction mixture was refluxed for an additional $6 \mathrm{~h}$. After removal of the solvent, the residue was dissolved in a minimum amount of chloroform and precipitated in cold methanol. The precipitate was placed into Soxhlet apparatus for extraction of the polymer using acetone (4h) and hexane (12h), respectively, to get rid of dimer, trimer and oligomers. Finally, the polymer was collected in chloroform and then precipitated in cold methanol as a dark purple solid (350 mg, yield $89 \%$ ). GPC data were reported as: Number-average molecular weight $\left(\mathrm{M}_{\mathrm{n}}\right)=18 \mathrm{kDa}$, Weight-Average molecular weight $\left(\mathrm{M}_{\mathrm{w}}\right)=28 \mathrm{kDa}$. Polydispersity index $(\mathrm{PDI})=1.55$.

Device fabrication and characterization.-Conventional PSCs with the architecture of ITO/PEDOT:PSS/Polymer: $\mathrm{PC}_{71} \mathrm{BM} / \mathrm{LiF} / \mathrm{Al}$ were fabricated using the following procedure. ITO coated glass substrates were cleaned in an ultrasonic bath in detergent water, water, isopropyl alcohol. It is followed by oxygen plasma cleaning to remove organic impurities from the surface of substrates. $40 \mathrm{~nm}$ thick PEDOT:PSS layer (Clevios V P A14083) was spin coated. Active layer solutions were dissolved in $o$-dichlorobenzene and spin coated in $\mathrm{N}_{2}$ filled MBraun glove box system. Various solvent additives were added to control the active layer morphology. $\mathrm{LiF}, \mathrm{Al}$ electrodes were evaporated under vacuum by thermal evaporator. Current density vs. voltage characteristics of the PSCs were determined under illumination of AM1.5G LOT-Quantum Design solar simulator calibrated by Rera Solutions reference solar cell. External quantum efficiency (EQE) measurements were carried out using monochromatic light, spectral response of the cells were recorded. The current density values were verified with EQE measurements.

\section{Results and Discussion}

Synthesis and characterization.--Syntheses of PTBS and PBTSe are shown in Schemes 1 and 2 and synthetic procedures are depicted in detail in the experimental part. Polymers were synthesized via Stille Coupling reaction with $\mathrm{Pd}\left(\mathrm{PPh}_{3}\right)_{2} \mathrm{Cl}_{2}$ as the catalyst in dry THF. PBTS and PBTSe reveal thermal stability with decomposition temperature at $5 \%$ weight loss at $327^{\circ} \mathrm{C}$ and $334^{\circ} \mathrm{C}$, respectively. High-temperature ranges for both polymers indicate that the film morphologies are stable according to Differential Scanning Calorimetry measurements. ${ }^{50}$

Electrochemical, spectroelectrochemical, optical and kinetic studies.-Electrochemical characterizations of PBTS and PBTSe were performed with cyclic voltammetry $(\mathrm{CV})$ in order to investigate both redox behaviors and HOMO-LUMO energy levels of polymers using GAMRY Instrument Potentiostat/Galvanostat/ZRA. During measurements, three electrode system was used in $0.1 \mathrm{M}$ tetrabutylammonium hexafluorophosphate $\left(\mathrm{TBAPF}_{6}\right) /$ acetonitrile $(\mathrm{ACN})$ electrolyte/solvent couple. For $\mathrm{CV}$ characterizations, the spray-coated thin films on ITO slides were prepared from the polymer/ $/ \mathrm{CHCl}_{3}$ 

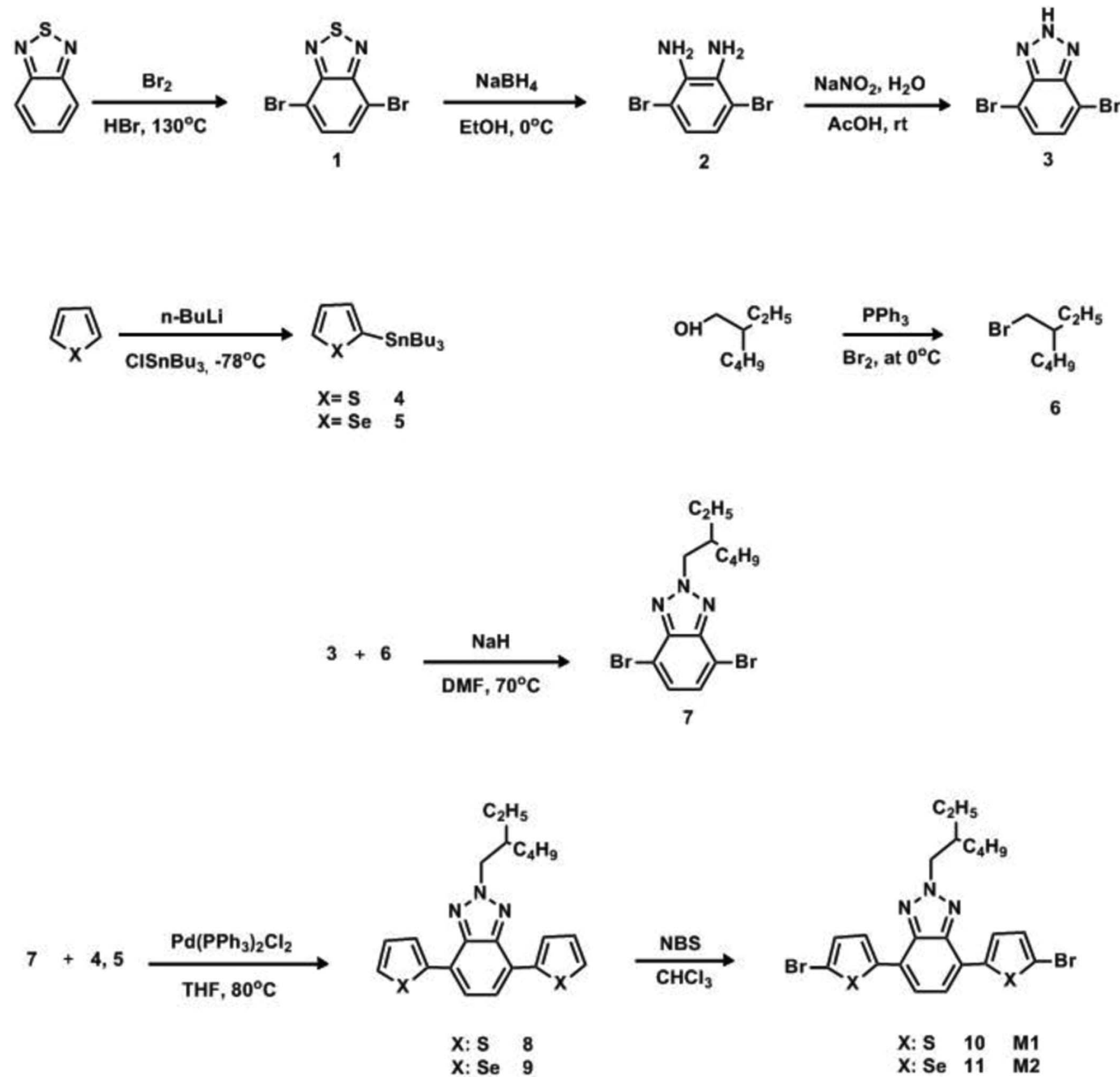

$\begin{array}{ll}X: S & 8 \\ X: S e & 9\end{array}$

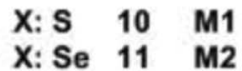

Scheme 1. Synthetic routes and chemical structures of the monomers.

solutions (2 mg/mL). Cyclic voltammograms (as depicted in Figure 1) were recorded in the potential range between $-2.0 \mathrm{~V}$ and $1.5 \mathrm{~V}$ for PBTS and between $-2.0 \mathrm{~V}$ and $1.3 \mathrm{~V}$ for PBTSe at a scan rate of $100 \mathrm{mV} / \mathrm{s}$. As reported in Table I, PBTSe exhibited lower redox potentials at $0.84 / 1.19 \mathrm{~V}$ (p-type doping) and $-1.52 \mathrm{~V} /-1.86 \mathrm{~V}$ (n-type doping) compared to those of PBTS at $0.93 \mathrm{~V} / 1.28 \mathrm{~V}$ (p-type doping) and -1.77 (n-type doping) which can be attributed to the electron-rich character of selenophene units in the PBTSe polymer backbone. Moreover, Se is more polarizable than S. The use of heavier chalcogens is a way to reduce the oxidation potentials of the resulting polymers. ${ }^{64,65}$

As seen in Figure 1, both polymers exhibited ambipolar characters, in other words, they have both $\mathrm{p}$ and n-type doping behaviors. HOMO and LUMO energy levels of conjugated polymers are crucial to test their usability in different applications, they can be calculated from CV results. HOMO and LUMO energy levels of PBTS and PBTSe were calculated from the onset of the oxidation/reduction potentials of the p-doping/n-doping states as $-5.29 \mathrm{eV} / 3.30 \mathrm{eV}$ and

Table I. Summary of electrochemical and spectroelectrochemical properties of PBTS and PBTSe.

\begin{tabular}{|c|c|c|c|c|c|c|c|}
\hline & $\mathrm{E}_{\mathrm{p} \text {-doping }}(\mathrm{V})$ & $\mathrm{E}_{\mathrm{n}-\text { doping }}(\mathrm{V})$ & HOMO (eV) & LUMO $(\mathrm{eV})$ & $\mathrm{Eg}_{\mathrm{g}}^{\mathrm{ec}}(\mathrm{eV})$ & $\lambda \max (\mathrm{nm})$ & $\mathrm{E}_{\mathrm{g}}{ }^{\mathrm{op}}(\mathrm{eV})$ \\
\hline PBTS & $0.93 / 1.28$ & -1.77 & -5.29 & -3.30 & 1.99 & $550 / 591$ & 1.84 \\
\hline PBTSe & $0.84 / 1.19$ & $-1.52 /-1.86$ & -5.36 & -3.50 & 1.86 & 580 & 1.78 \\
\hline
\end{tabular}




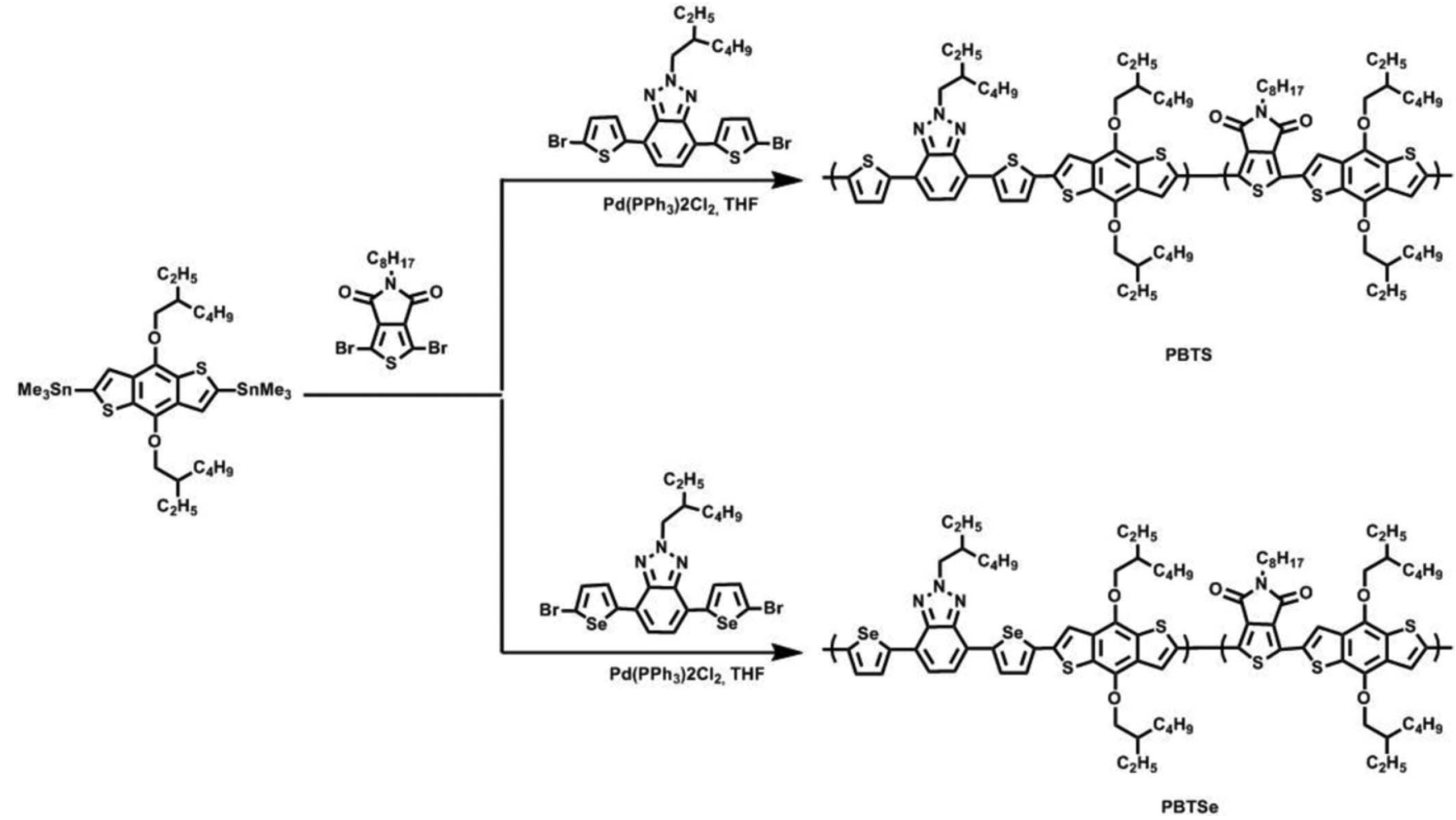

Scheme 2. Synthetic routes and chemical structures of the PBTS and PBTSe polymer.

$-5.36 \mathrm{eV} /-3.50 \mathrm{eV}$, respectively. Following equations were used for HOMO/LUMO energy level calculations according to reference energy level of ferrocene/ferrocenium redox couple $(4.75 \mathrm{eV}$ below the vacuum level).

$$
\begin{aligned}
& E_{\text {Номо }}(\mathrm{eV})=-\left(4.75+E_{\text {oxidation, onset }}\right) \\
& E_{\text {LUMO }}(\mathrm{eV})=-\left(4.75+E_{\text {reduction, onset }}\right)
\end{aligned}
$$

All electrochemical results are summarized in Table I. The lower redox potentials of Se comprising PBTSe can be attributed to the different electron densities on polymer chains. The stronger electron donating ability of selenophene unit increases the electron density in the polymer backbone and enables doping/dedoping process at lower potentials. $^{66}$

The optical changes were explored via spectroelectrochemical studies and incrementally increasing potentials were applied during recording UV-Vis spectra, for both PBTS and PBTSe. For spectroelectrochemical studies, polymers were dissolved in $\mathrm{CHCl}_{3}$ as described before and spray-coated on ITO coated glass electrodes, then dipped into $0.1 \mathrm{M} \mathrm{TBAPF}_{6} / \mathrm{ACN}$ solutions in order to investigate their absorption characters between $0 \mathrm{~V}$ and $1.8 \mathrm{~V}$ for both polymers.

As seen in Figure 2, neutral state absorption bands were recorded at $550 \mathrm{~nm}$ and $580 \mathrm{~nm}$ for PBTS and PBTSe, which corresponded to the $\pi-\pi^{*}$ inter-band transitions. During the stepwise potential applications, while the corresponding neutral absorptions were depleted, new (a)

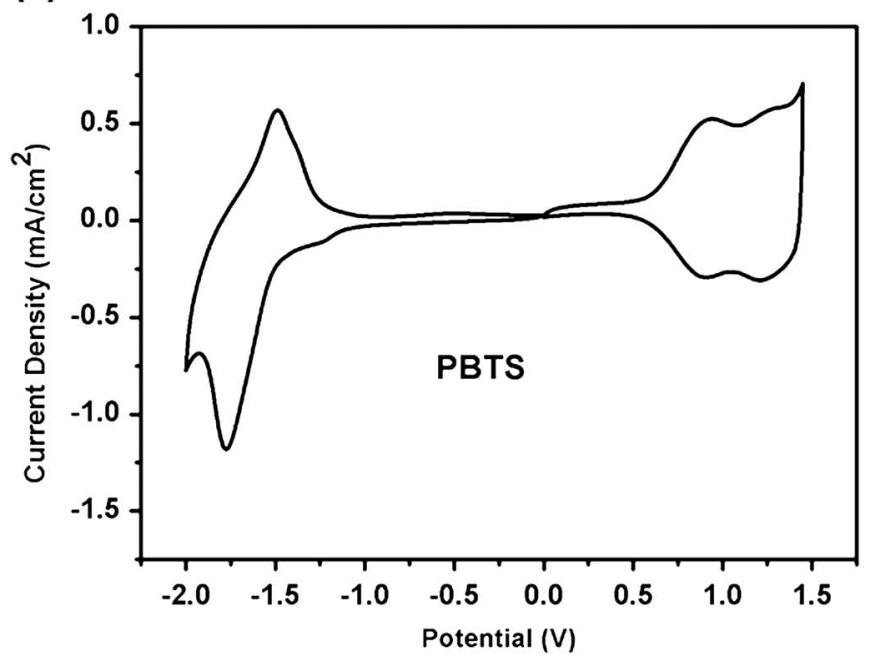

(b)

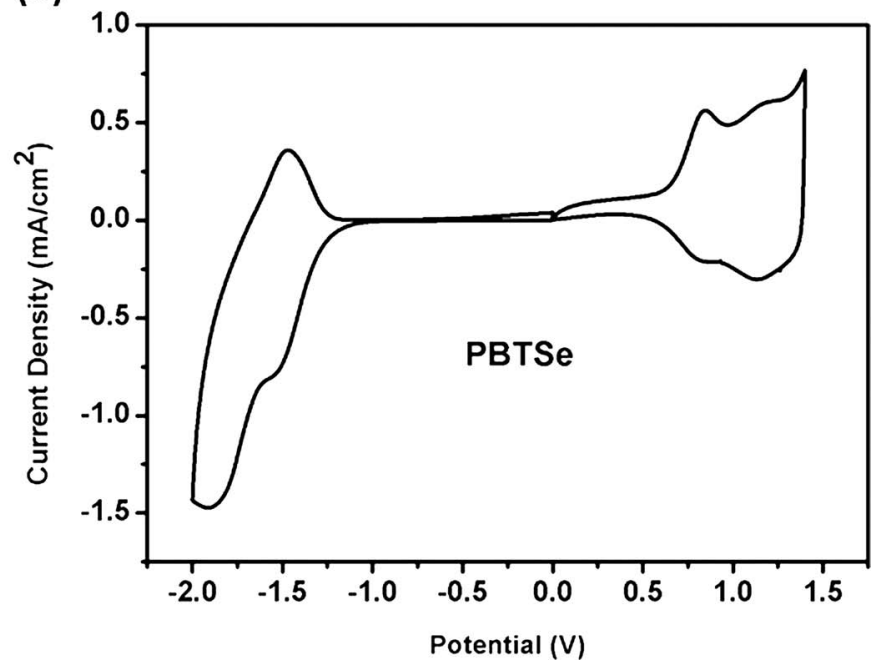

Figure 1. Single scan cyclic voltammograms of PBTS (a) and PBTSe (b) in 0.1 M TBAPF $/ \mathrm{ACN}$ electrolyte solution. 
(a.1.)

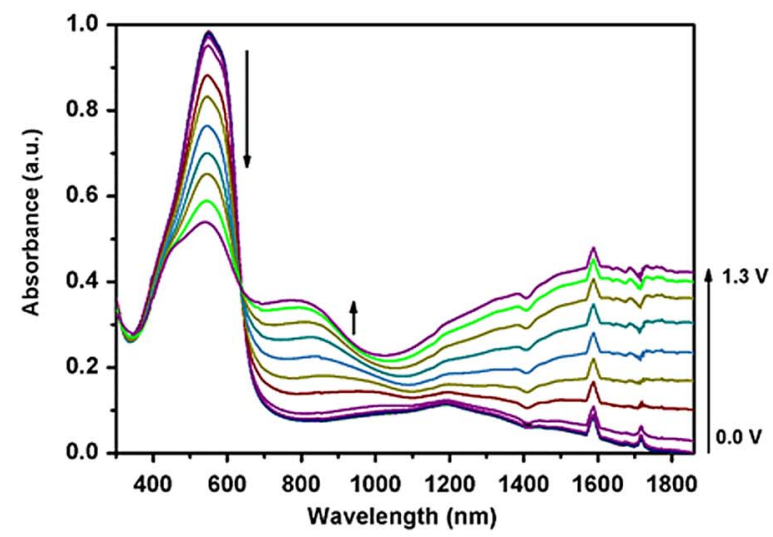

(b.1.)

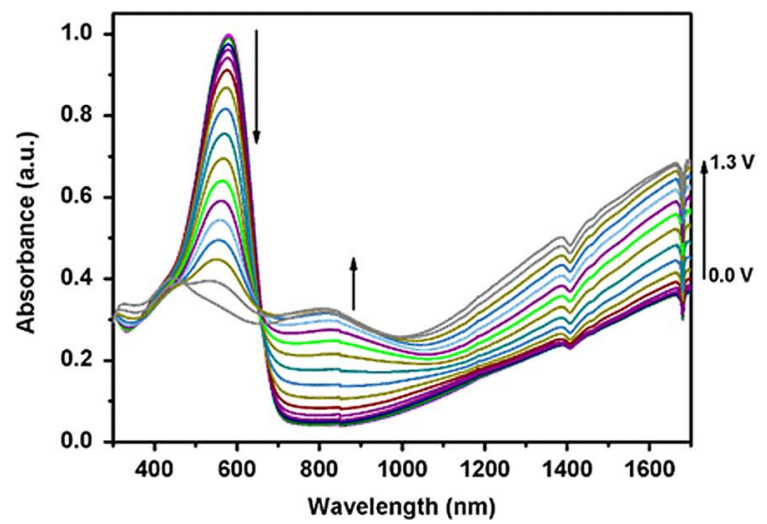

(a.2.)
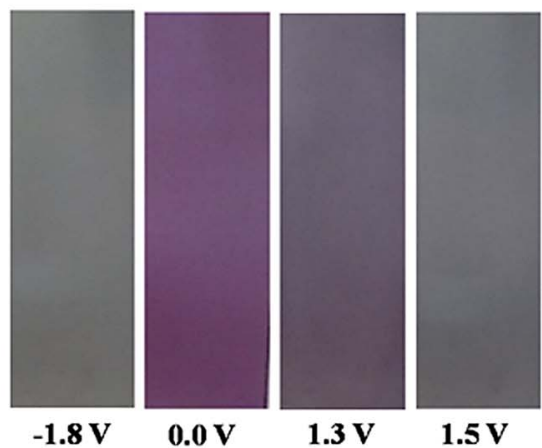

(b.2.)

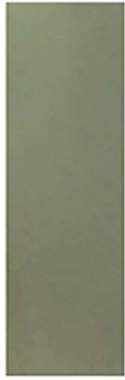

$-1.8 \mathrm{~V}$

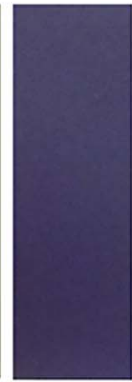

$0.0 \mathrm{~V}$

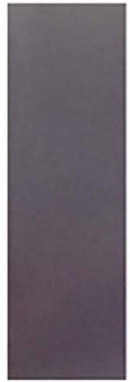

$0.9 \mathrm{~V}$

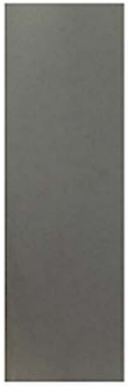

$1.1 \mathrm{~V}$

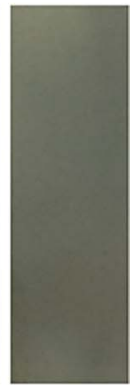

$1.2 \mathrm{~V}$

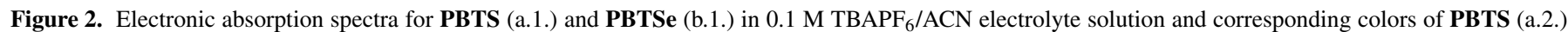
and PBTSe (b.2.) in the neutral, oxidized and reduced forms.

absorption bands appeared at around $800 \mathrm{~nm}$ and $1600 \mathrm{~nm}$. The formation of the new bands at longer wavelengths proves the formation of polaronic and bipolaronic charge carriers on the polymer backbone.

The optical band gaps of both polymers were calculated from the onset absorption wavelengths of the $\pi-\pi^{*}$ transitions as $1.84 \mathrm{eV}$ and $1.78 \mathrm{eV}$, respectively for PBTS and PBTSe. Similar to the electrochemical results, the stronger electron donating ability of selenophene unit compared to that of thiophene group increases the electron density in the polymer chain which resulted in the redshift in the neutral state absorption and lower bandgap for Se comprising PBTSe (Table I).

Furthermore, both polymers exhibited electrochromic and multichromatic behaviors which make them also applicable in different fields such as electrochromic devices, smart windows, etc. As depicted in Figure 2, PBTS showed reddish-purple and gray while PBTSe exhibited dark violet and greenish-gray color in the neutral and oxidized states with different intermediate colors. Additionally, both PBTS and PBTSe exhibited electrochromic behaviors (gray and green colors, respectively) in their n-doped states.

The optical properties of both PBTS and PBTSe were investigated as a film and in a dilute chloroform solution and the results were depicted in Figures $3 \mathrm{a}$ and $3 \mathrm{c}$. Maximum absorptions in solution and thin film were recorded at $550 \mathrm{~nm} / 581 \mathrm{~nm}$ and $550 \mathrm{~nm} / 591 \mathrm{~nm}$ for PBTS and $577 \mathrm{~nm}$ and $580 \mathrm{~nm}$ for PBTSe, respectively. PBTS exhibited a $10 \mathrm{~nm}$ redshift in the thin film, but PBTSe showed very similar absorptions in both forms with a $3 \mathrm{~nm}$ redshift. The red shifts in the thin films could be dedicated to the more ordered structures of $\pi$-conjugated polymers, higher conjugation length and intermolecular polymer chains' interactions. ${ }^{67}$ In addition, PL emission spectra of PBTS and PBTSe both in dilute chloroform and film states were shown in Figures $3 b$ and 3d. PBTS and PBTSe showed large Stoke's shifts of $192 \mathrm{~nm}$ and $162 \mathrm{~nm}$ in their film states, respectively. The interchain exciton transportation is proved by the difference of PL spectra in solution and in the film of PBTS and PBTSe copolymers. Bathochromic shift was observed for the film with respect to solution by virtue of improved interchain exciton migration in the solid states. ${ }^{68}$

Kinetic studies were performed in order to calculate and report the optical contrast and switching time values. The measurements were performed at their $\lambda_{\max }$ values determined from spectroelectrochemical studies between the two extreme states (neutral and fully oxidized states) of the polymers by applying a potential for $5 \mathrm{~s}$. Switching time is the time needed for one full switch between the two extreme states and optical contrast is the transmittance change between those states. It can be concluded from Figure 4 and Table II that both polymers showed promising optical contrasts and moderate switching times at their corresponding $\lambda_{\max }$ values. The highest optical contrasts recorded for thiophene comprising PBTS are $28 \%$ at $550 \mathrm{~nm}$ and $23 \%$ at $800 \mathrm{~nm}$ and those for selenophene based PBTSe is $30 \%$ at $580 \mathrm{~nm}, 52 \%$ at $825 \mathrm{~nm}$. Corresponding switching times are also illustrated in Table II.

Table II. Summary of kinetic studies of PBTS and PBTSe.

Optical contrast $(\Delta \mathrm{T} \%)$ Wavelength (nm) Switching times (s)

$\begin{array}{llll}\text { PBTS } & 28 & 550 \mathrm{~nm} & 3.2 \\ \text { PBTSe } & 23 & 800 \mathrm{~nm} & 4.9 \\ & 30 & 580 \mathrm{~nm} & 3.4 \\ & 52 & 825 \mathrm{~nm} & 5.6\end{array}$


(a)

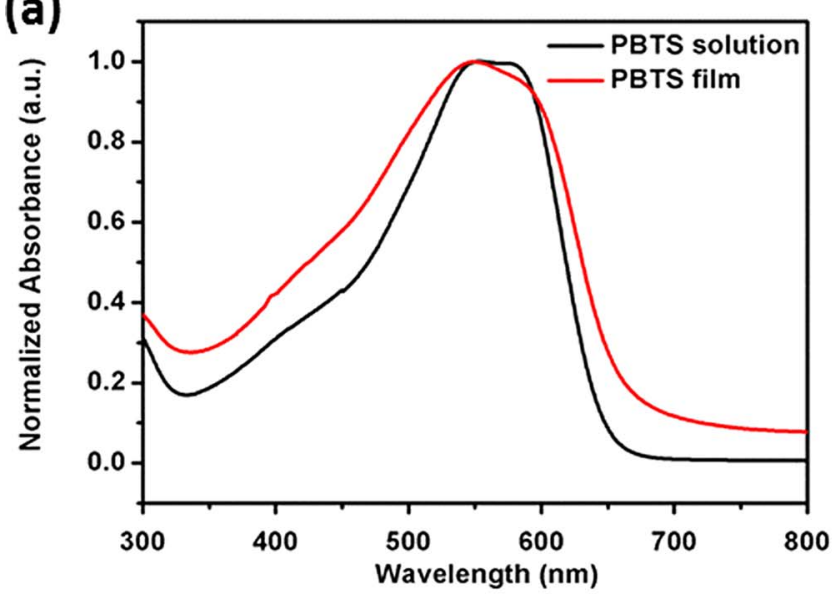

(c)

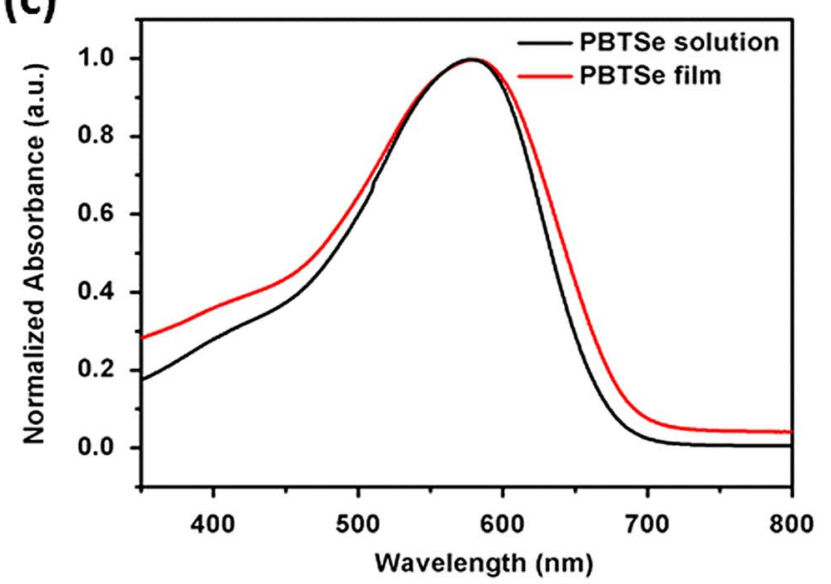

(b)

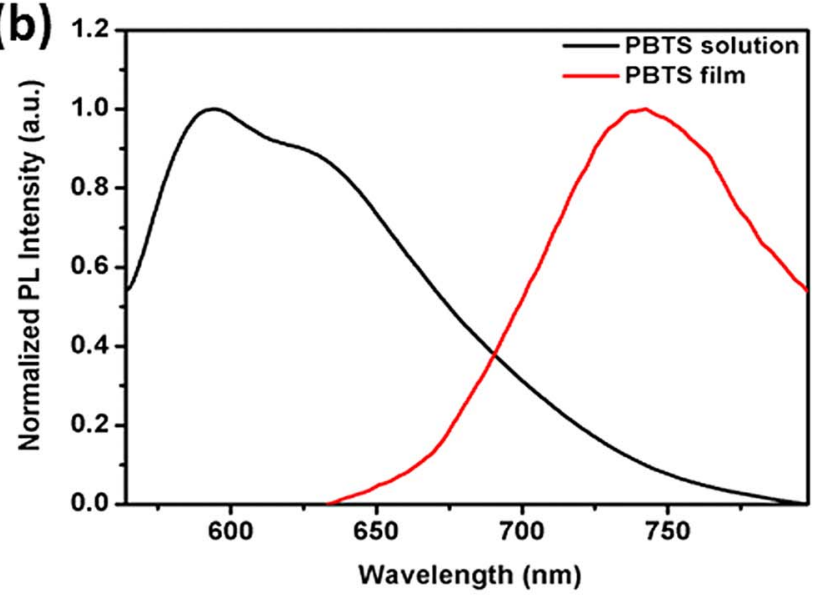

(d)

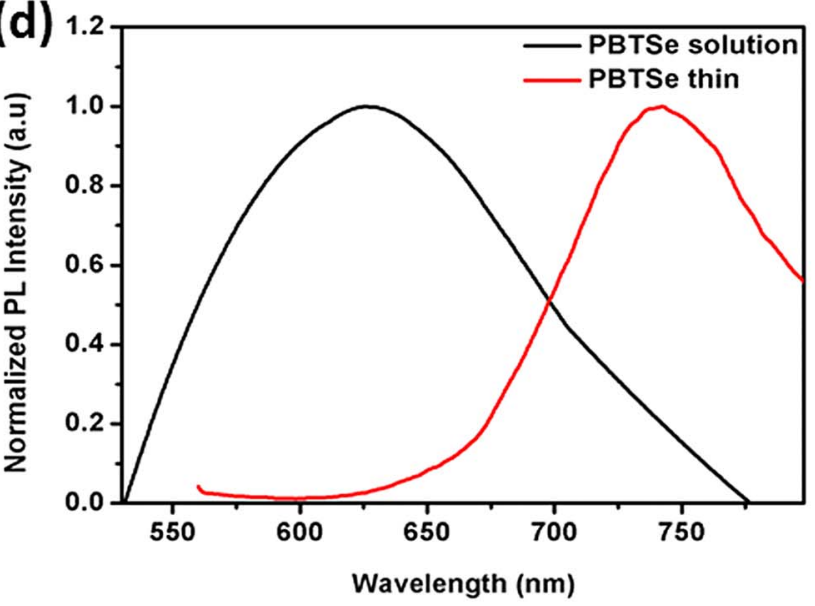

Figure 3. Normalized absorption and photoluminescence spectra of polymers in chloroform and in thin film form.

(a)

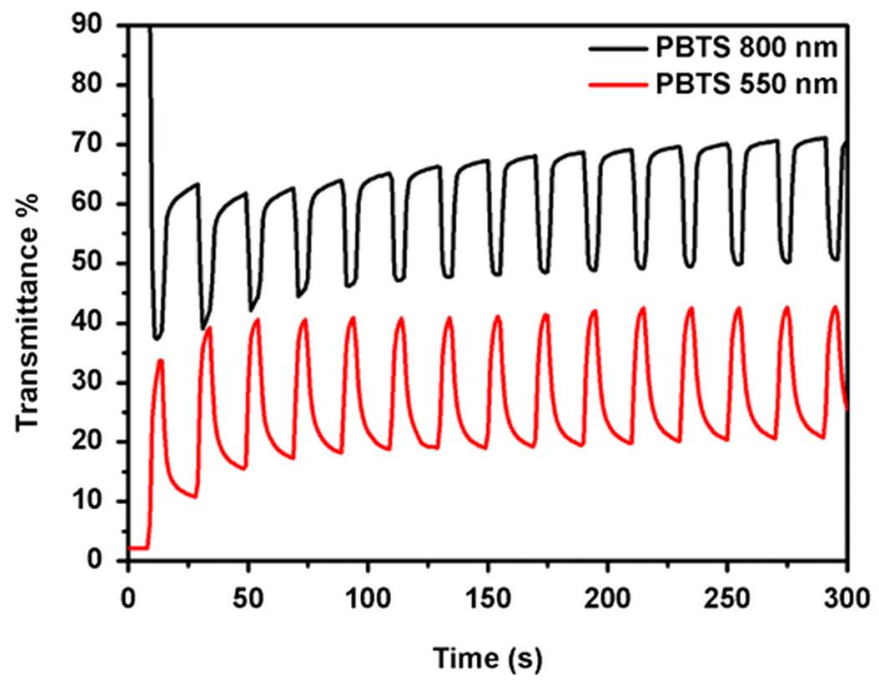

(b)

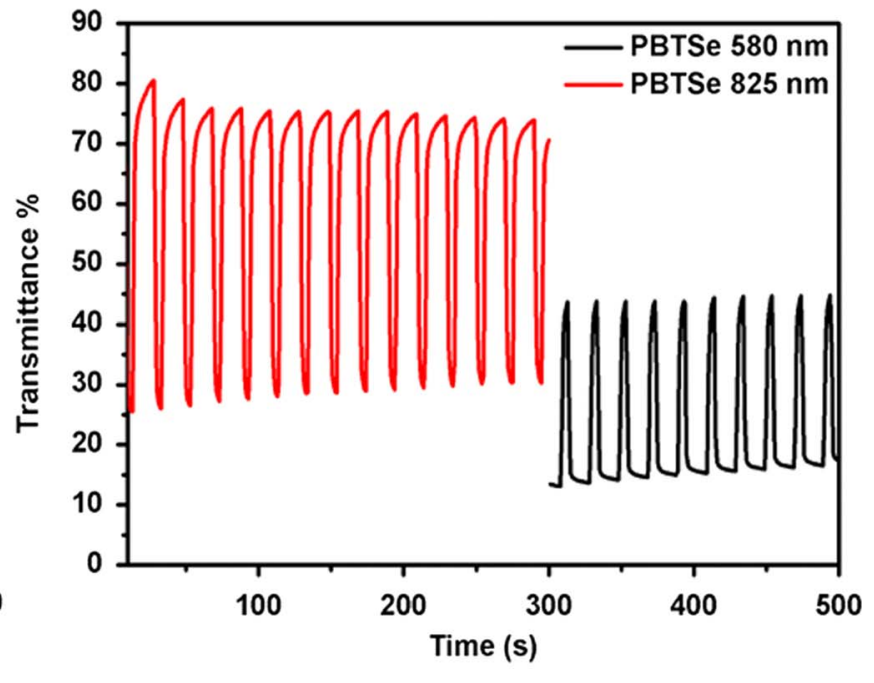

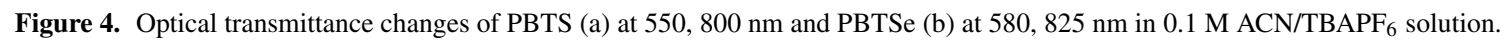



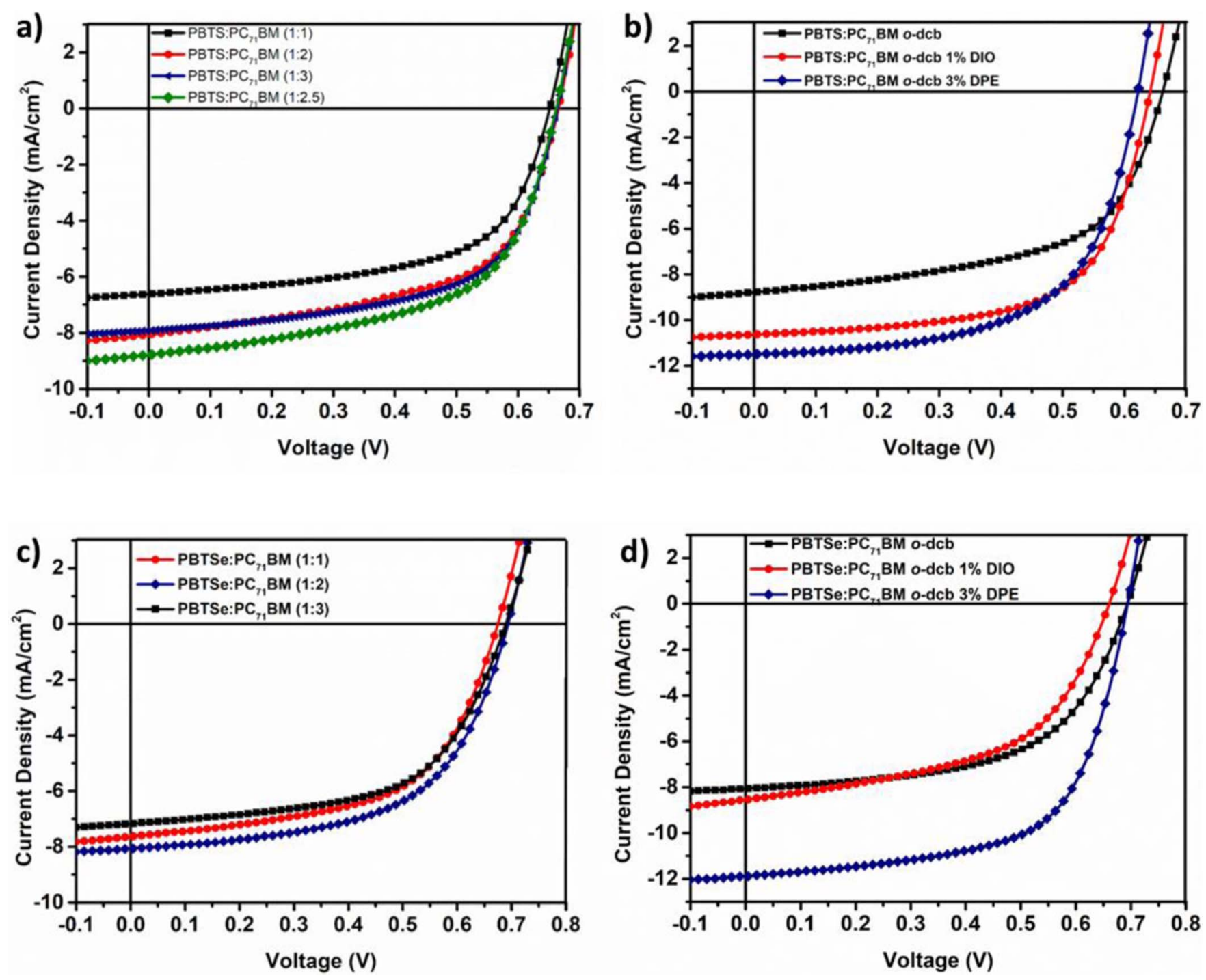

Figure 5. J-V characteristics of the PSCs based on PBTS and PBTSe.

Photovoltaic studies.-The conventional BHJ photovoltaic devices were fabricated with the following structural order; ITO/PEDOT:PSS/PBTS-PBTSe:PCBM/LiF/Al. Details of the device fabrication were emphasized in experimental section. The current density vs. voltage curves of PSCs fabricated with varying polymer $\mathrm{PC}_{71} \mathrm{BM}$ ratios and DIO and DPE solvent additives are shown in Figures 5a, 5b, 5c, 5d and their respective device metrics were listed in Table III.

The optimum PBTS:PC ${ }_{71}$ BM polymer solar cell with a weight ratio of $(1: 2.5, \mathrm{w} / \mathrm{w})$ exhibited a PCE of $3.32 \%$ with a $\mathrm{V}_{\mathrm{OC}}$ of $0.66 \mathrm{~V}$, a $\mathrm{J}_{\mathrm{SC}}$ of $8.79 \mathrm{~mA} / \mathrm{cm}^{2}$ and a $\mathrm{FF}$ of $57.2 \%$ without any additive. PSCs based on PBTS: $\mathrm{PC}_{71} \mathrm{BM}(1: 2.5, \mathrm{w} / \mathrm{w})$ active layers processed from $o$-dcb and $1 \%$ vol DIO offered a PCE of $4.30 \%$ through mainly a rise in $\mathrm{FF}$ and $\mathrm{J}_{\mathrm{SC}}$ values. Addition of DPE as the processing additive resulted in similar enhancements in FF and PCE for the devices based on PBTS with the addition of DIO. 4.29\% PCE value was achieved.

PBTSe:PC71BM (1:2) device exhibited a PCE of $3.19 \%$ with a $\mathrm{V}_{\mathrm{OC}}$ of $0.69 \mathrm{~V}$, a $\mathrm{J}_{\mathrm{SC}}$ of $8.06 \mathrm{~mA} / \mathrm{cm}^{2}$ and a $\mathrm{FF}$ of $57.3 \%$ without any solvent additive. In this study, insertion of selenophene $\pi$-spacer instead of thiophene moiety, was utilized as an effective strategy to achieve higher PCE values. Since selenium atoms have larger overlap of $\pi$ orbitals, selenophene bearing polymers show higher conductivity and charge mobility than thiophene bearing

analogs. Moreover, selenophene comprising polymers have lower $\mathrm{E}_{\mathrm{g}}$ values.

Higher power conversion efficiencies were achieved by replacement of thiophene with selenophene in literature. ${ }^{69,70}$ It is an effective strategy for design of semiconducting polymers where the LUMO energy level can be lowered while almost not affecting the HOMO level due to smaller ionization potential. Thus, higher $\mathrm{J}_{\mathrm{SC}}$ values can be attained without comprising $\mathrm{V}_{\mathrm{OC}}$. As depicted in Table III, PSCs comprising selenophene containing polymer PBTSe attained higher $\mathrm{J}_{\mathrm{SC}}$ values than that of thiophene containing PBTS analog at 1:1 and 1:2 weight ratios. The higher $\mathrm{J}_{\mathrm{SC}}$ value in case of PBTSe means a large number of incoming photons from the solar spectrum can be absorbed in selenophene containing solar cell device. ${ }^{69} \mathrm{~V}_{\mathrm{OC}}$ values are directly proportional to the difference between HOMO energy level of the polymer and the LUMO energy level of acceptor. Higher $\mathrm{V}_{\mathrm{OC}}$ values were obtained for the PSCs with PBTSe due to deeper lying HOMO level.

Exciton dissociation and charge carrier transport strongly depend on the arrangement of electron donor and electron acceptor groups. ${ }^{71,72}$ Adjustment of active morphology can be achieved by using common solvent additives such as 1,8 diiodooctane (DIO), diphenyl ether (DPE) and 1-chloronaphthalene (CN). ${ }^{19}$ In our study, the device performance based on PBTS increased from $3.32 \%$ to $4.30 \%$ and $4.29 \%$ at 1:2.5 weight ratio (PBTS:PC ${ }_{71} \mathrm{BM}$ ) by introducing DIO (1vol \%) 
Table III. Device metrics of polymer solar cells based on PBTS and PBTSe with various D/A ratios and addition of additives.

\begin{tabular}{|c|c|c|c|c|c|c|}
\hline & Solvent & $\mathrm{V}_{\mathrm{OC}}(\mathrm{V})$ & $\mathrm{J}_{\mathrm{SC}}\left(\mathrm{mA} / \mathrm{cm}^{2}\right)$ & $\mathrm{FF}(\%)$ & PCE $(\%)$ & Treatment \\
\hline \multicolumn{7}{|c|}{ PBTS:PC 71 BM } \\
\hline 1:1 & $o$-dcb & 0.65 & 6.62 & 59.7 & $2.57(2.36)^{* *}$ & - \\
\hline 1:2 & $o-\mathrm{dcb}$ & 0.66 & 8.03 & 57.9 & $3.07(2.95)$ & - \\
\hline $1: 3$ & $o$-dcb & 0.66 & 7.89 & 60.6 & $3.16(3.06)$ & - \\
\hline $1: 2.5$ & $o-\mathrm{dcb}$ & 0.66 & $8.79(8.05)^{*}$ & 57.2 & $3.32(3.16)$ & - \\
\hline $1: 2.5$ & $o$-dcb & 0.64 & $10.57(9.92)$ & 63.5 & $4.30(4.05)$ & $1 \%$ DIO \\
\hline $1: 2.5$ & $o$-dcb & 0.62 & $11.50(10.76)$ & 60.1 & $4.29(3.96)$ & $3 \%$ DPE \\
\hline \multicolumn{7}{|c|}{ PBTSe:PC ${ }_{71}$ BM } \\
\hline 1:1 & $o$-dcb & 0.67 & 7.62 & 57.2 & $2.92(2.84)$ & - \\
\hline 1:2 & $o$-dcb & 0.69 & $8.06(7.66)$ & 57.3 & $3.19(2.91)$ & - \\
\hline $1: 3$ & $o$-dcb & 0.69 & 7.15 & 58.2 & $2.87(2.69)$ & - \\
\hline $1: 2$ & $o$-dcb & 0.66 & $8.55(8.11)$ & 52.5 & $2.96(2.81)$ & $1 \% \mathrm{DIO}$ \\
\hline 1:2 & $o$-dcb & 0.69 & $11.88(11.26)$ & 62.7 & $5.15(4.90)$ & 3\% DPE \\
\hline
\end{tabular}

*Jsc values derived from EQE curves were given in parentheses.

**Average PCE of ten devices.
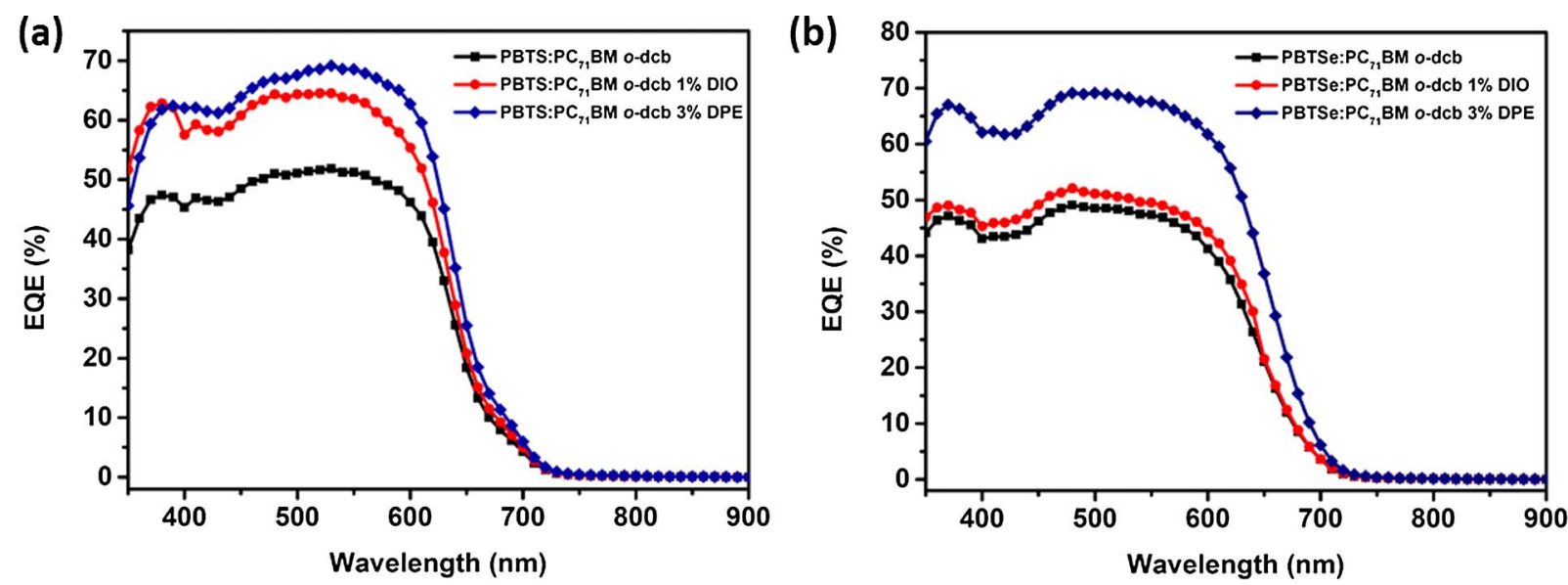

Figure 6. EQE curves of PBTS (a) and PBTSe (b) based PSCs.
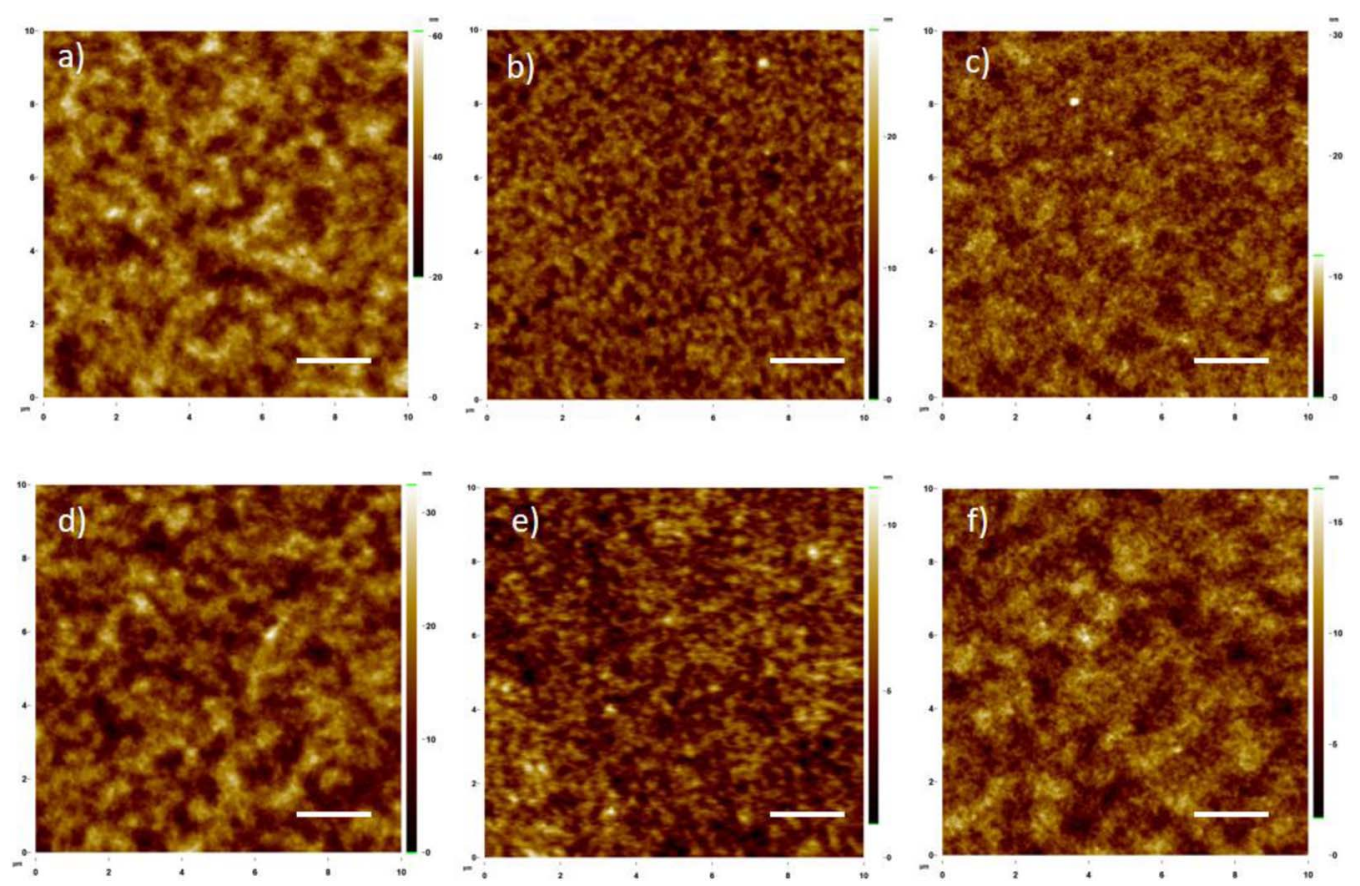

Figure 7. AFM images of a) PBTS: $\mathrm{PC}_{71} \mathrm{BM}$ b) PBTS: PC ${ }_{71} \mathrm{BM}$ with DIO additive c) PBTS: $\mathrm{PC}_{71} \mathrm{BM}$ with DPE additive d) PBTSe: PC ${ }_{71} \mathrm{BM}$ ) PBTSe: PC ${ }_{71} \mathrm{BM}$ with DIO additive f) PBTSe: PC $_{71}$ BM with DPE additive. Scale bar is $200 \mathrm{~nm}$. 

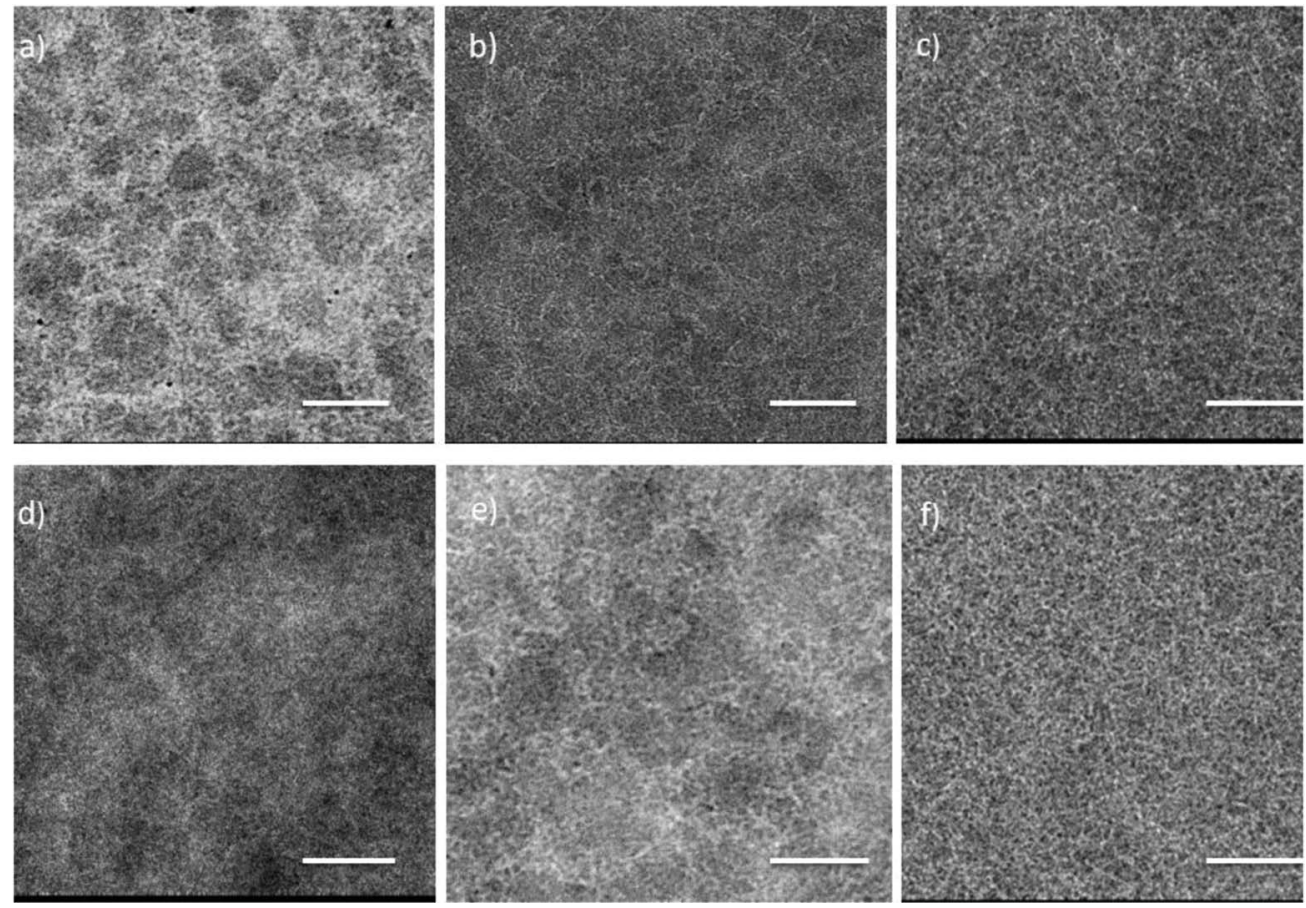

Figure 8. TEM images of a) PBTS: $\mathrm{PC}_{71} \mathrm{BM}$ b) PBTS: $\mathrm{PC}_{71} \mathrm{BM}$ with DIO additive c) PBTS: $\mathrm{PC}_{71} \mathrm{BM}$ with DPE additive d) PBTSe: PC 71 BM e) PBTSe: PC ${ }_{71} \mathrm{BM}$ with DIO additive f) PBTSe:PC 71 BM with DPE additive. Scale bar is $200 \mathrm{~nm}$.

and DPE (3 vol\%), respectively. DPE (3 vol \%) was added to the active layer to obtain better morphology and PCE was increased from $3.19 \%$ to $5.15 \%$ at $1: 2$ (PBTSe: PC $_{71} \mathrm{BM}$ ) (Table III).

The device performances using PBTS and PBTSe were verified with External Quantum Efficiency (EQE) measurements as shown in Figures $6 \mathrm{a}$ and $6 \mathrm{~b}$. $\mathrm{J}_{\mathrm{SC}}$ values calculated from EQE spectra were listed in Table III, are consistent with the ones obtained from $\mathrm{J}-\mathrm{V}$ curves. Broad monochromatic spectra were obtained for both PBTS and PBTSe based polymer solar cells both with a peak value of almost $70 \%$.

\section{Morphology}

The bi-continuous network structure is required to achieve better performance for devices since the domain sizes are important for excitons (hole-electron pair) to reach the donor-acceptor interface where charge generates. ${ }^{73}$ Morphology control is a critical issue for a solar cell with fullerenes since the p-type donor and n-type acceptor materials cause spontaneous phase separation. There are several strategies to obtain uniform nanoscale morphology of the active layer and one of the simple and effective methods is introducing solvent additive to host solvent. The topographical and morphological properties of the active layers were studied by atomic force microscopy (AFM) and transmission electron microscopy (TEM), respectively (Figures 7 and 8). Addition of DIO to the active layer containing PBTS: $\mathrm{PC}_{71} \mathrm{BM}(1: 2.5$, $\mathrm{w} / \mathrm{w}$ ) diminishes the generation of large domains as seen in Figure $7 \mathrm{~b}$ since DIO can dissolve selectively fullerenes and aggregated $\mathrm{PC}_{71} \mathrm{BM}$ molecules can intercalate into polymer chain domains. ${ }^{74,75}$ In the case of PBTSe:PC ${ }_{71} \mathrm{BM}(1: 2, \mathrm{w} / \mathrm{w})$ comprising active layer, with the addition of DPE, phase seperated active layer morphology was achieved (Figure 8f) compared to Figure 8d. It is known that DPE acts like a theta solvent where polymer chains can behave as an ideal mixture forming nano-fibrillar morphology. ${ }^{75}$ It is seen from AFM and TEM images, almost pinhole free films were formed.

\section{Conclusions}

In the present study, two medium-bandgap conjugated terpolymers, PBTS and PBTSe (containing benzotriazole, benzodithiophene, and thienopyrrolodione with different $\pi$-bridges) were synthesized and PSC device fabrications were studied. Synthesized polymers were used as the donor units and were blended with $\mathrm{PC}_{71} \mathrm{BM}$. By exchanging the thiophene $\pi$ bridge with selenophene, the performance of devices was improved through a rise in $\mathrm{J}_{\mathrm{SC}}$ values. Solvent processing additives DIO and DPE with parent $o$-dcb solvent yielded the best device performances with 1:2.5 and 1:2 weight ratios of PBTS and PBTSe with $\mathrm{PC}_{71} \mathrm{BM}$, respectively. Under these observations, introducing $\pi-$ spacers in $\pi$-conjugated polymer chains and optimizations via altering fullerene ratios and using solvent additives can be effective strategies to obtain better performances for organic photovoltaic cells.

\section{Acknowledgments}

Authors like to thank Nanomagnetic Instruments for AFM studies and Central Laboratory at METU for TEM images. Akrema thanks TUBITAK for financial assistance through 2216 program.

\section{ORCID}

Ali Cirpan (D) https://orcid.org/0000-0003-3051-8380

\section{References}

1. I. International Energy Agency, World Energy Outlook, 2014, OECD (2014) https: //www.oecd-ilibrary.org/energy/world-energy-outlook-2014_weo-2014-en.

2. K. Zweibel, in Thin Film Solar Cells, p. 427, John Wiley \& Sons, Ltd, Chichester, UK (2006).

3. G. Li, R. Zhu, and Y. Yang, Nat. Photonics, 6, 153 (2012)

4. A. J. Heeger, Adv. Mater., 26, 10 (2014).

5. C. J. Brabec, M. Heeney, I. McCulloch, and J. Nelson, Chem. Soc. Rev., 40, 1185 (2011).

6. J. Peng, L. Lu, and H. Yang, Renew. Sustain. Energy Rev., 19, 255 (2013).

7. T. Bhattacharya, A. K. Chakraborty, and K. Pal, J. Sol. Energy, 2014, 1 (2014).

8. V. V. Tyagi, N. A. A. Rahim, N. A. Rahim, and J. A. L. Selvaraj, Renew. Sustain. Energy Rev., 20, 443 (2013).

9. A. Poullikkas, Renew. Sustain. Energy Rev., 1, 30 (2007).

10. S. E. Shaheen, R. Radspinner, N. Peyghambarian, and G. E. Jabbour, Appl. Phys. Lett., 79, 2996 (2001).

11. G. Gustafsson et al., Nature, 357, 477 (1992). 
12. S. Günes, H. Neugebauer, and N.S. Sariciftci, Chem. Rev, 107, 1324 (2007).

13. A. L. Roes, E. A. Alsema, K. Blok, and M. K. Patel, Prog. Photovoltaics Res. Appl., $17,372(2009)$.

14. L. Dou et al., Adv. Mater, 25, 6642 (2013).

15. Z. He et al., Nat. Photonics, 6, 591 (2012).

16. J. You et al., Nat. Commun., 4, 1446 (2013).

17. M. A. Green, E. D. Dunlop, D. H. Levi, J. Hohl-Ebinger, M. Yoshita, and A. W. Y. Ho-Baillie, Prog. Photovolt Res. Appl., 27, 565 (2019).

18. L. Bian, E. Zhu, J. Tang, W. Tang, and F. Zhang, Prog. Polym. Sci., 37, 1292 (2012).

19. L. Lu et al., Chem. Rev., 115, 12666 (2015).

20. Z. Liu et al., Sol. Energy Mater. Sol. Cells, 189, 103 (2019).

21. F. C. Krebs, Sol. Energy Mater. Sol. Cells, 93, 394 (2009).

22. S. Chen et al., J. Am. Chem. Soc., 139, 6298 (2017).

23. W. Abdelaziz, A. Shaker, M. Abouelatta, and A. Zekry, Opt. Mater. (Amst)., 91, 239 (2019).

24. M. H. Hoang et al., J. Mater. Chem. C, 7, 111 (2019).

25. W. Zhao et al., Adv. Mater, 28, 4734 (2016).

26. L. Meng et al., Science (80-.)., 361, 1094 (2018).

27. Y. He and Y. Li, Phys. Chem. Chem. Phys., 13, 1970 (2011).

28. J. Nelson, Mater. Today, 14, 462 (2011).

29. H. Sun et al., Energy Environ. Sci., 12, 3328 (2019).

30. X.-X. Zhan et al., Sol. Energy Mater. Sol. Cells, 176, 340 (2018).

31. G. Sauvé and R. Fernando, J. Phys. Chem. Lett., 6, 3770 (2015).

32. J. Peet et al., Nat. Mater., 6, 497 (2007).

33. H.-Y. Chen et al., Nat. Photonics, 3, 649 (2009).

34. L.-L. Deng et al., Sci. Bull., 61, 132 (2016).

35. J. Chen et al., Adv. Energy Mater., 7, 1601344 (2017).

36. P. Cheng, G. Li, X. Zhan, and Y. Yang, Nat. Photonics, 12, 131 (2018).

37. S. C. Price, A. C. Stuart, and W. You, Macromolecules, 43, 4609 (2010).

38. P. Deng et al., Dye. Pigment., 134, 251 (2016).

39. X. Guo, M. Zhang, C. Cui, J. Hou, and Y. Li, ACS Appl. Mater. Interfaces, 6(11) 8190 (2014).

40. J. Zhao et al., Nat. Energy, 1, 15027 (2016).

41. C. C. Chueh et al., Energy Environ. Sci., 6, 3241 (2013).

42. S. H. Park et al., Nat. Photonics, 3, 297 (2009).

43. D. Patra et al., Macromol. Chem. Phys., 212, 1960 (2011).
44. F. Zhang et al., Adv. Funct. Mater, 16, 667 (2006).

45. M.-H. Chen et al., Adv. Mater, 21, 4238 (2009).

46. T. E. Kang, K.-H. Kim, and B. J. Kim, J. Mater. Chem. A, 2, 15252 (2014).

47. H. J. Cho et al., Nano Energy, 39, 229 (2017).

48. S. Qu et al., Macromolecules, 50, 4962 (2017).

49. T. Ma et al., Adv. Energy Mater., 5, 1501282 (2015).

50. S.-M. Bang et al., Dye. Pigment., 140, 229 (2017).

51. S. Suganya, N. Kim, J. Y. Jeong, and J. S. Park, Polymer (Guildf)., 116, 226 (2017).

52. C. Cabanetos et al., J. Am. Chem. Soc., 135, 4656 (2013).

53. C. Lee et al., Chem. Mater, 29, 9407 (2017).

54. Ö. Azeri et al., Polymer (Guildf)., 133, 60 (2017).

55. S. S. Zade, N. Zamoshchik, and M. Bendikov, Chem. - A Eur. J., 15, 8613 (2009).

56. Y. H. Wijsboom et al., Angew. Chemie, 121, 5551 (2009).

57. L. Li, J. Hollinger, A. A. Jahnke, S. Petrov, and D. S. Seferos, Chem. Sci., 2, 2306 (2011).

58. S. D. Oosterhout, M. M. Wienk, M. Al-Hashimi, M. Heeney, and R. A. J. Janssen, J Phys. Chem. C, 115, 18901 (2011).

59. M. İ. Özkut, S. Atak, A. M. Önal, and A. Cihaner, J. Mater. Chem., 21, 5268 (2011)

60. D. S. Chung et al., Org. Electron., 11, 899 (2010).

61. W.-H. Lee et al., J. Polym. Sci. Part A Polym. Chem., 50, 551 (2012).

62. K. A. Mazzio, M. Yuan, K. Okamoto, and C. K. Luscombe, ACS Appl. Mater. Inter faces, 3, 271 (2011).

63. B. A. D. Neto, A. A. M. Lapis, E. N. da Silva Júnior, and J. Dupont, European J. Org. Chem., 2013, 228 (2013).

64. F. A. Devillanova and W.-W. Du Mont, Handbook of Chalcogen Chemistry, Royal Society of Chemistry, Cambridge (2007).

65. D. Cortizo-Lacalle, P. J. Skabara, and T. D. Westgate, in, p. 99

66. J.-M. Jiang et al., Macromolecules, 47, 7070 (2014).

67. I. Meager et al., J. Am. Chem. Soc., 135, 11537 (2013).

68. G. M. Farinola et al., Materials (Basel)., 3, 3077 (2010).

69. H.-Y. Chen, S.-C. Yeh, C.-T. Chen, and C.-T. Chen, J. Mater Chem., 22, 21549 (2012)

70. L. Gao et al., Adv. Mater., 28, 8288 (2016).

71. X. Zhu et al., Sol. Energy Mater. Sol. Cells, 132, 528 (2015).

72. P. W. M. Blom, V. D. Mihailetchi, L. J. A. Koster, and D. E. Markov, Adv. Mater, 19 1551 (2007).

73. C. V. Hoven et al., Adv. Mater, 22, E63 (2010).

74. H. N. Tran, D. H. Kim, S. Park, and S. Cho, Curr. Appl. Phys., 18, 534 (2018).

75. T. H. Lee et al., RSC Adv., 7, 7476 (2017). 